\title{
PENINGKATAN LITERASI MAHASISWA SEJARAH TERHADAP SUMBER PRIMER MELALUI KUNJUNGAN DAN SOSIALISASI DI DEPO ARSIP DINAS PERPUSTAKAAN DAN KEARSIPAN KABUPATEN CIREBON
}

\author{
Aditia Muara Padiatra, Juhaeriyah \\ IAIN Syekh Nurjati Cirebon, Indonesia \\ aditiamuara@gmail.com
}

\begin{abstract}
Sources in history occupy an important position, the absence of sources means that historical narrative cannot be carried out and will only become narrative without being based on clear grounds, since history will not be written without the accompanying sources. Once the meaning of this source is crucial, then literacy related to this source becomes important to do. History students as the vanguard of a new generation of historians in the future need to know how important the shape and position of these sources are. In this regard, the socialization and service visits to the archives depot of the Cirebon Regency Library and Archives Service were carried out. from the results of this activity it was known that some students had a great interest in archival knowledge and from these activities there was an increase in student literacy regarding archival management and archive function in his study as a primary source in historical science.
\end{abstract}

Keywords : Literacy, Students, History, Archives, Primary Sources

\begin{abstract}
Abstrak
Sumber dalam sejarah menempati posisi yang penting, ketiadaan sumber sendiri mengakibatkan narasi sejarah tidak akan dapat dilakukan dan hanya sebatas pengkisahan tanpa berdasarkan pada dasaran yang jelas, berhubung sejarah tidak akan ditulis tanpa adanya sumber yang menyertainya. Begitu krusialnya arti sumber ini, maka pemahaman literasi terkait dengan sumber ini menjadi penting untuk dilakukan. Mahasiswa sejarah sebagai garda terdepan dari generasi baru para sejarawan dimasa mendatang perlu untuk mengetahui bagaimana bentuk dan posisi penting dari sumber tersebut. Berkaitan dengan hal itu, maka sosialisasi dan kunjungan pengabdian ke depo arsip dinas Perpustakaan dan Kearsipan Kabupaten Cirebon kemudian dilakukan, dari hasil kegiatan ini diketahui bahwa sebagian mahasiswa mempunyai minat yang besar terhadap pengetahuan arsip dan dari kegiatan tersebut terjadi peningkatan literasi mahasiswa mengenai tata kelola kearsipan dan fungsi arsip dalam telaahnya sebagai sumber primer dalam keilmuan sejarah.
\end{abstract}

Kata Kunci : Literasi, Mahasiswa, Sejarah, Arsip, Sumber Primer

Submitted: 2020-09-08

Revised: $2020-09-21$

Accepted: 2020-09-22

\section{Pendahuluan}

Literasi merupakan suatu hal yang penting dalam dunia pendidikan, tanpa adanya literasi yang baik maka mutu pendidikan yang terselenggara tentunya tidak akan berjalan dengan sempurna. Meruntut daripada hal tersebut literasi secara sederhana diartikan sebagai keberaksaran (Gol A Gong, 2012) atau kemampuan dalam melakukan kegiatan pembacaan terhadap aksara. Guna menelaah dan mempelajari sebuah keilmuan tertentu, kemampuan literasi tentunya menjadi krusial dan menjadi agensi penting dalam mencetak generasi-generasi unggul yang nantinya akan berkiprah didalam kehidupan bermasyarakat. Gerakan "melek literasi" merupakan sebuah wacana yang perlu untuk digulirkan dalam lingkungan serta habitat masyarakat akademik, dalam statusnya di 
lingkup keilmuan manapun, berhubung sifatnya yang sangat umum dan mencakup semua hal dibidang kependidikan dan pengajaran. Namun, dalam praktikalnya kegiatan literasi ini tentunya mempunyai sifat dan bentuknya dengan penyesuaian di lingkup keilmuan masing-masing, seperti dalam keilmuan sejarah yang amat berhubungan dengan konteks literasi dimana tulisan-tulisan yang ada pada masa lalu, yang biasa disebut sebagai arsip, merupakan bahan penelaahan bagi para sejarawan (sebutan bagi para peneliti di bidang kesejarahan) untuk dapat merangkai peristiwa-peristiwa yang telah terjadi dimasa lalu guna berbagai kepentingan, baik yang sifatnya publik maupun akademik.

Sejarah sendiri merupakan suatu keilmuan yang memfokuskan diri pada penelaahan sebuah peristiwa atau kejadian yang ada pada masa yang telah lalu. Sejarah dalam hal ini mempunyai beberapa pengertian, seperti peristiwa-peristiwa yang menyangkut manusia dalam kehidupan bermasyarakat dimasa lampau (Kartodirdjo, 2016), pengalaman kolektif di masa lampau (Notosusanto, 1965), ataupun sebagai rekonstruksi dari masa yang telah berlalu (Kuntowijoyo, 2005). Namun terlepas dari kesemua hal tersebut, sejarah sendiri kita amini sebagai suatu bagian dari diri kita dan dekat dengan keseharian serta telah membudaya di tengah kehidupan yang kita lakukan. Seseorang yang tidak mempunyai (atau bahkan terkadang ada yang tidak mau mengakui) pengetahuan akan sejarahnya sendiri ibarat sebuah pohon namun tanpa akar yang mengikatnya, sebagaimana artian dari sejarah secara etimologis yang berasal dari kata syajaratun, yang berarti pohon dimana sejarah selalu menjadi latar belakang dari setiap manusia, dalam tumbuh kembangnya seseorang dari ketika Ia dilahirkan ke dunia, bahkan mungkin sampai dengan menjelang ajalnya (Padiatra, 2020).

Dalam keilmuan sejarah sendiri, kegiatan literasi terhadap sumber-sumber kesejarahan menjadi penting artiannya, utamanya terhadap pembacaan guna rekonstruksi peristiwa-peristiwa yang ada dimasa lalu. Sumber-sumber kesejarahan ini mempunyai beragam bentuk, dari yang bentuknya tekstual, lisan, visual, sampai dengan kebendaan. Sumber-sumber inipun kemudian masih harus dibagi lagi menjadi 2 (dua) kategori, yakni primer dan sekunder. Kesemua bentuk sumber-sumber tersebut merupakan sarana telaah bagi para sejarawan untuk kemudian dapat menalaah kejadian yang pada masa yang telah lewat atau lalu. Dalam hal ini, sumber dokumen yang notabenenya paling umum untuk digunakan oleh para sejarawan ketika melakukan telaah merupakan salah satu sumber penting yang perlu untuk diketahui.

Mahasiswa sejarah, yang dalam hal ini bertindak sebagai generasi-generasi baru sejarawan di masa depan tentunya memerlukan bekal-bekal keilmuan guna menjalani kegiatan akademik perkuliahan dimana sumber-sumber tersebut merupakan kegiatan penelahaan rutin yang harus mereka ketahui dan diharapkan pada nantinya dapat diaplikasikan dalam kehidupannya masing-masing begitu mereka lulus pada nantinya. Melalui kegiatan kunjungan dan sosialisasi ke depo arsip diharapkan mahasiswamahasiswa yang ada dapat mengetahui serta belajar mengenai apa artian dari sumber primer yang selama ini menjadi bagian penting dalam kegiatan penulisan peristiwa ataupun kisah kejadian di masa lalu. 


\section{Metode}

Kegiatan ini dilaksanakan sebagai perwujudan dari pengamalan tridharma perguruan tinggi, khususnya dibidang pengabdian masyarakat bagi dosen Jurusan Sejarah Kebudayaan Islam Fakultas Ushuluddin Adab dan Dakwah (UAD) IAIN Syekh Nurjati Cirebon. Target daripada kegiatan ini adalah para mahasiswa semester 1 (satu) Jurusan Sejarah Kebudayaan Islam Fakultas UAD IAIN Syekh Nurjati Cirebon. Rencana kedepannya kegiatan ini dapat rutin dilaksanakan guna pengetahuan dasar, utamanya terhadap sumber-sumber primer (Poerwantana, 1992) bagi para mahasiswa tingkat awal Jurusan Sejarah Kebudayaan Islam dan diharapkan dapat berpengaruh terhadap peningkatan literasi dikalangan mahasiswa/siswi yang telah melaksanakan kegiatan kunjungan serta sosialisasi tersebut, berhubung sumber-sumber arsip merupakan salah satu dari bahan penting rekonstruksi dari penulisan peristiwa dalam kaidah keilmuan sejarah dan tentunya akan dipraktekkan pada mata kuliah-mata kuliah yang akan mereka jalani pada semester-semester perkuliahan berikutnya.

Kegiatan ini sendiri dibagi atas beberapa tahapan, yang antara lain termaktub sebagai berikut :

1. Persiapan

a. Melakukan kontak awal dengan dinas Perpustakaan dan Kearsipan Kabupaten Cirebon untuk menelusuri kemungkinan pelaksanaan kegiatan yang niatannya ingin diselenggarakan di depo Arsip Dinas Perpustakaan dan Kearsipan Kabupaten Cirebon dan prosedur yang sekiranya harus dijalankan berkaitan dengan pelaksanaan acara kegiatan, serta menentukan pertemuan awal untuk membahas kegiatan.

b. Observasi berupa survey ke tempat atau Lembaga dimana kegiatan tersebut akan rencananya diadakan, dalam hal ini pertemuan dilaksanakan di depo Arsip dinas Perpustakaan dan Kearsipan Kabupaten Cirebon. Dalam hal ini dilakukan penelusuran lebih dalam mengenai tujuan diadakan kegiatan sosialisasi yang niatannya ingin di inisiasi serta koordinasi lebih lanjut mengenai teknis acara yang akan dilakukan

c. Pembahasan mengenai bentuk sosialisasi yang akan dilakukan, dalam hal ini dilaksanakan dengan melakukan diskusi dengan para stakeholder atau pemangku kepentingan terkait yang dalam hal ini diwakili dengan pihak dinas Perpustakaan dan Kearsipan Kabupaten Cirebon mengenai materi sosialisasi yang akan disajikan serta rundown daripada kegiatan yang akan dilangsungkan.

2. Pelaksanaan

Pelaksanaan kegiatan ini dilakukan secara tatap muka langsung dengan bentuk penyajian ceramah dan diskusi yang dipandu. Sosialisasi ini sendiri terbagi atas beberapa materi yang antara lain sebagai berikut :

a. Pemahaman dasar mengenai sejarah dan sumber dalam kaidah keilmuan sejarah

b. Pemaparan materi mengenai arsip dan jenis-jenis arsip yang terdapat dilingkungan dinas Perpustakaan dan Kearsipan Kabupaten Cirebon 
c. Substansi hubungan antara arsip dan sumber primer dalam rekonstruksi peristiwa di masa lalu serta tantangan-tantangan yang kemudian dihadapi dalam proses penelahaan tersebut

Kegiatan pelaksanaan sosialisasi ini mengambil tempat di ruangan auditorium dinas Perpustakaan dan Kearsipan Kabupaten Cirebon pada tanggal 18 November 2019. Pada pelaksanaannya sendiri, antusiasme para peserta terlihat pada pertanyaan-pertanyaan yang diajukan oleh peserta berkaitan dengan materi yang disampaikan. Dengan bentuk sosialisasi yang digabungkan dengan studi lapangan, para mahasiswa dalam hal ini berkesempatan untuk melihat berbagai arsip yang tersedia di depo arsip dinas Perpustakaan dan Kearsipan Kabupaten Cirebon, sehingga membuat mereka pada akhirnya menjadi jelas akan sumber-sumber tersebut dan menganggap bahwasanya sumber-sumber tersebut nyatanya dekat dan tidak sulit untuk dapat ditemukan. Hal ini kemudian menjadikan tujuan serta maksud daripada terselenggaranya acara sosialisasi tersebut dapat tersampaikan dengan cepat.

\section{Hasil dan Pembahasan}

Kegiatan pelaksanaan pengabdian yang berupa sosialisasi ini mengambil tempat di ruangan auditorium dinas Perpustakaan dan Kearsipan Kabupaten Cirebon dalam hal ini berjalan dengan cukup lancar. Hasil analisis yang didapatkan adalah para mahasiswasiswi yang ikut hadir dan menjadi peserta diacara tersebut dapat mencerna materi dari kegiatan sosialisasi yang dilakukan. Sosialisasi dijalankan dengan bentuk ceramah terpadu dengan 2 (dua) orang narasumber yang masing-masing berasal dari Jurusan Sejarah Kebudayaan Islam F-UAD IAIN Syekh Nurjati Cirebon dan Arsiparis Ahli dari dinas Perpustakaan dan Kearsipan Kabupaten Cirebon, setelahnya dilakukan tanya jawab yang dipandu oleh 1 (satu) orang moderator dari pihak dinas Perpustakaan dan Kearsipan Kabupaten Cirebon dan diikuti oleh 75 orang peserta yang merupakan mahasiswa sejarah kebudayaan Islam semester 1 IAIN Syekh Nurjati Cirebon.

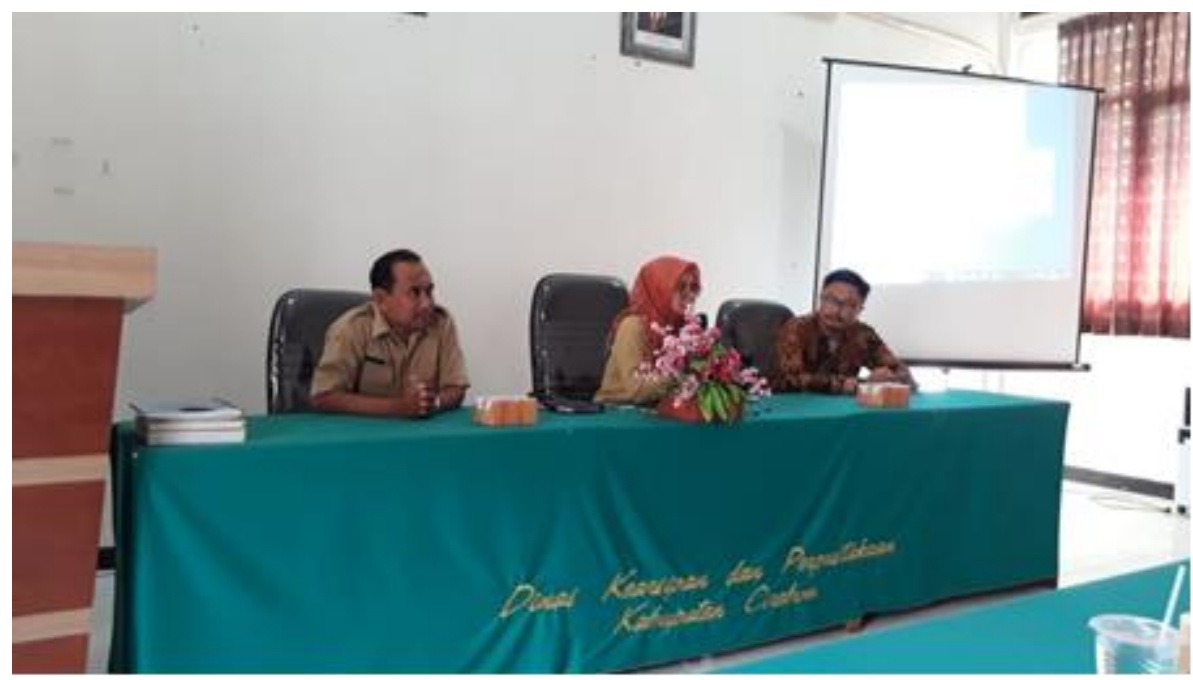

Gambar 1. Para narasumber 
Kegiatan pengabdian yang dilakukan ini sendiri menghasilkan beberapa point, antara lain, pertama, berupa peningkatan pengetahuan mengenai pentingnya arsip dalam kehidupan bermasyarakat, dimana arsip merupakan sebuah cermin waktu dari perjalanan sebuah masyarakat yang ada disuatu wilayah ataupun tertentu sehingga perlu terus dilakukan upaya pelestarian dan pemanfaatan secara rutin dan berkelanjutan agar tercipta suatu gambaran sejarah yang utuh, yang kemudian akan menjadi pegangan bagi para generasi dimasa yang akan datang, disisi lain pemahaman mengenai perlakuan terhadap arsip yang notabenenya merupakan lembaran dokumen - dokumen ataupun naskah yang sudah lapuk dimakan usia sehingga memerlukan penanganan yang khusus dalam memeliharanya.

Hal ini menjadi titik tolak bagi mahasiswa agar kemudian senantiasa menjaga dokumen-dokumen seperti arsip tersebut untuk kemudian dapat ditelaah guna kepentingan rekonstruksi masa lalu. Berhubung dalam hal ini ternyata lazim diketahui bahwasanya beberapa mahasiswa-siswi yang mempunyai afiliasi terhadap institusiinstitusi keislaman tradisional, seperti pesantren juga mempunyai naskah manuskrip lama yang dapat dijadikan sebagai arsip, dan diantara mereka sendiri kurang begitu mengetahui tentang tata cara perawatan dan pemeliharaannya, sehingga ada beberapa kemudian yang teronggok dan bahkan dimakan sebagian oleh ngengat atau rayap.

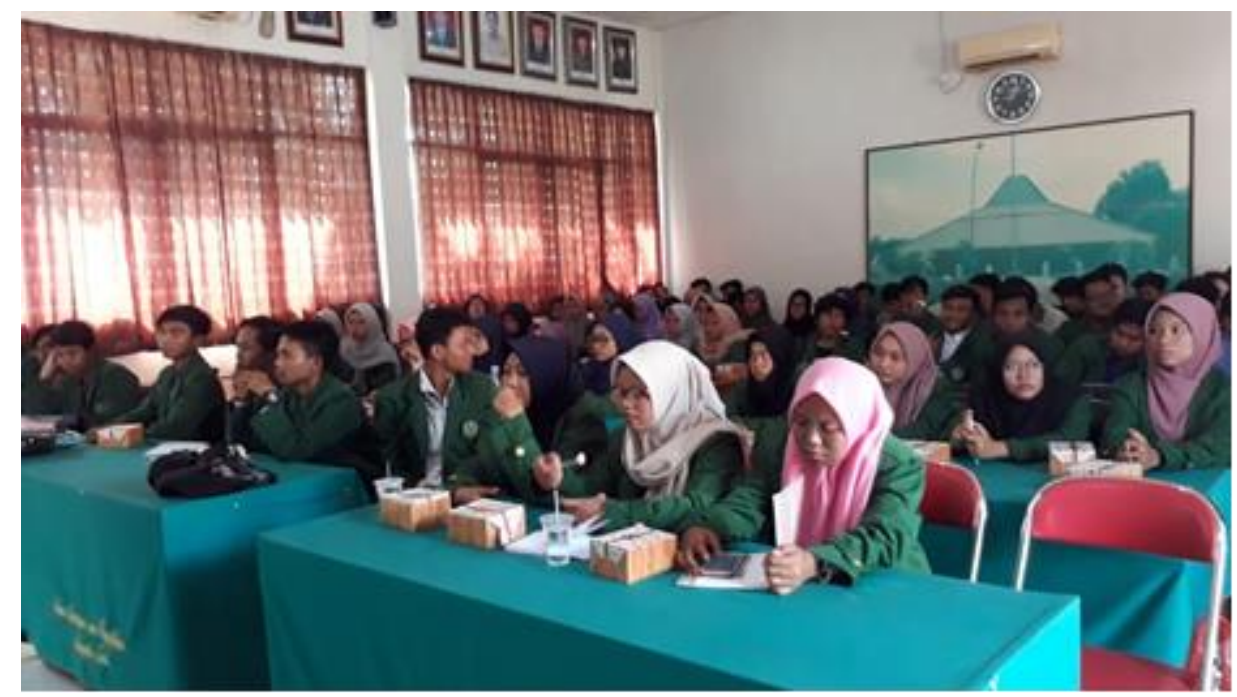

Gambar 2. Peserta kegiatan

Meruntut daripada hal tersebut, arsip dalam hal ini mempunyai beberapa nilai kegunaan, menurut (Wursanto, 1991) beberapa kegunaan tersebut apabila dijabarkan antara lain ialah :

\section{Arsip yang mempunyai nilai Informasi}

Dalam hal ini, nilai informasi yang dikandung oleh arsip ialah karena arsip, yang dalam hal ini merupakan dokumen berkenaan dengan suatu kegiatan tertentu, tentunya mengandung informasi mengenai suatu hal yang melingkupinya. Dengan demikian arsip dalam hal ini dapat menjelaskan suatu perkara ataupun urusan. Contoh arsip dalam hal ini ialah seperti : brosur, pengumuman, dan lain sebagainya. 
2. Arsip yang mempunyai nilai historis

Dalam hal ini, arsip bertindak sebagai salah satu sumber sejarah, mempunyai nilai historis dalam mengungkapkan peristiwa yang sekiranya telah berlalu. Arsip dalam hal ini mempunyai kegunaan dalam meneroka peristiwa yang telah terjadi pada masa lalu untuk kemudian dihadirkan kembali pada masa kini dengan berbagai rupa, baik tulisan maupun kilasan diorama. Hal ini berhubung arsip merupakan bentuk yang terus abadi apabila dirawat dan dilestarikan dengan baik. Contoh arsip yang berkenaan dengan hal ini antara lain : Arsip pengembangan wilayah, arsip pencatatan negara, dokumen silsilah, catatancatatan organisasi atau keanggotaan di masa lalu, dan lain sebagainya.

3. Arsip yang mempunyai nilai yuridis

Arsip yang mempunyai nilai yuridis dalam hal ini ialah arsip yang mempunyai kandungan suatu peristiwa atau hal-hal tertentu dalam tataran yuridis, arsip ini dapat pula dijadikan sebagai alat bukti dalam perikehidupan bermasyarakat, berhubung bentuk arsip ini yang formal dan sah dimata hukum. Contoh arsip ini antara lain ialah : akte kelahiran, ijazah, kartu tanda penduduk, surat izin mengemudi, dan lain sebagainya.

4. Arsip yang mempunyai nilai guna ilmiah

Arsip yang mempunyai nilai guna ilmiah dalam hal ini ialah arsip yang mempunyai fungsi dalam membantu kemajuan daripada ilmu pengetahuan. Arsip jenis ini dapat dijadikan sebagai pedoman dan landasan untuk menemukan hal-hal serta pengetahuan yang sifatnya baru. Contoh dari jenis arsip ini antara lain ialah : catatan perkuliahan, hasil penelitian, jurnal, buku-buku referensi, dan lain sebagainya.

\section{Arsip yang mempunyai guna finansial}

Yang dimaksud dengan arsip ini ialah arsip yang mempunyai kegunaan sebagai suatu alat bukti pembayaran ataupun yang berkaitan dengan persoalan serta permasalahan keuangan. Arsip jenis ini dapat pula dijadikan sebagai bukti penerimaan dalam hal keuangan. Jenis arsip yang berkenaan dengan hal ini antara lain ialah seperti nota, kwitansi, surat hutang, serta lain sebagainya.

6. Arsip yang mempunyai guna organisasi

Arsip ini merupakan jenis arsip yang berkenaan dengan tata Kelola pada suatu organisasi yang ada di masyarakat. Arsip ini dapat dijadikan sebagai suatu sarana pendukung demi kepentingan dan kemajuan suatu organisasi dimana arsip tersebut dibuat. Jenis arsip dalam hal ini ialah seperti laporan keanggotaan, kegiatan acara organisasi, dan lain sebagainya.

\section{Arsip yang mempunyai guna administrasi}

Yang dimaksud dengan arsip ini ialah arsip yang digunakan untuk membantu suatu pengurusan terkait dengan tata kelola tertentu atau menjadi suatu alat bantu dalam mendukung suatu pelaksanaan kegiatan, sehingga suatu kegiatan tersebut dapat berjalan dengan baik dan lancar. Beberapa contoh arsip berkenaan dengan hal ini antara lain ialah : Arsip tata usaha, arsip pengelolaan keuangan dan keanggotaan, dan lain sebagainya. 
8. Arsip yang mempunyai guna politik

Arsip dari jenis ini ialah arsip yang berkenaan dengan prosedur kerja daripada suatu lingkup kerjasama yang berdasar pada kesamaan pemikiran atau idealisme tertentu. Jadi arsip ini sendiri lebih banyak dipergunakan sebagai sarana penguatan kelompok dan pembantu dalam pelaksanaan tugas Kerjasama antara pihak yang satu dengan pihak lainnya.

Berdasarkan jenis-jenis arsip dan berbagai macam kegunaannya tersebut maka sudah menjadi hal yang penting agar kemudian arsip dapat dikelola dengan baik, sehingga arsip dalam hal ini dapat digunakan dan dimanfaatkan sesuai dengan peruntukan dan kepentingan para penelaahnya. Hal ini menjadi penting dan tentunya harus disosialisasikan agar kemudian para generasi penerus dapat menyadari akan pentingnya arsip dan kegunaannya dalam meneroka perjalanan sejarah bangsanya.

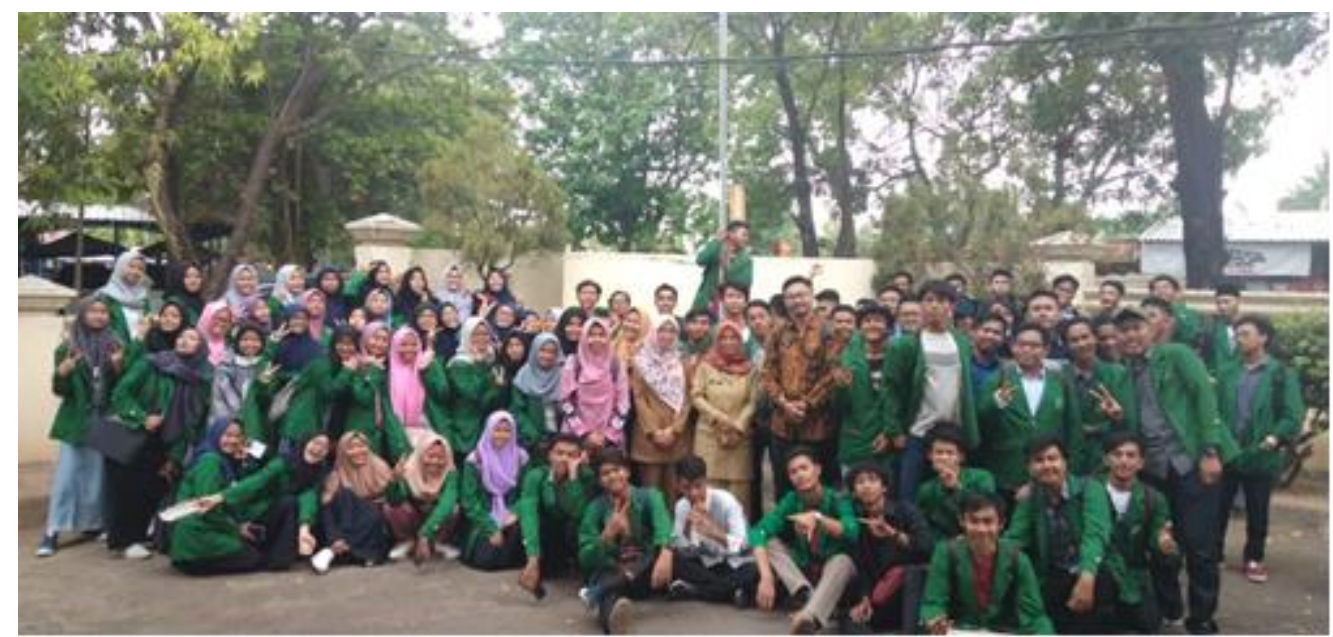

Gambar 3. Narasumber dan para peserta kegiatan

Prosesi kegiatan sosialisasi berjalan dengan semakin baik setelah kemudian pihak dinas Perpustakaan dan Kearsipan Kabupaten Cirebon berkenan untuk membuka depo penyimpanan arsip untuk kemudian dapat dilihat oleh para mahasiswa-siswi guna kemudian mereka teroka dan diskusikan. Hal ini menjadi keuntungan bagi para mahasiswa-siswi yang dapat melihat arsip yang notabenenya merupakan sumber primer langsung dari tempat penyimpanannya sendiri, sehingga diharapkan ini dapat menjadi pengalaman yang unik, yang sekiranya dapat menjadikan mereka semakin memahami akan pentingnya arsip dan pengelolaannya di kemudian hari. Respon yang positif juga dikeluarkan oleh dinas Perpustakaan dan Kearsipan Kabupaten Cirebon yang niatannya bersedia untuk menjadikan acara kegiatan ini sebagai agenda rutin yang akan terselenggara pada setiap tahunnya guna kepentingan edukasi dan mempererat kerjasama antara kedua belah pihak sebagai bagian dari tridharma perguruan tinggi.

\section{Kesimpulan}

Hasil kegiatan yang diperoleh melalui kegiatan sosialisasi dan kunjungan ke depo arsip dinas Perpustakaan dan Kearsipan Kabupaten Cirebon, Jawa Barat dapat disimpulkan bahwa upaya pemanfaatan arsip sebagai salah satu sumber primer 
merupakan hal yang penting bagi kegiatan akademik kesejarahan. Hal ini menjadikan arsip, sebagai salah satu sumber telaah dalam keilmuan sejarah menjadi perlu untuk dilestarikan dalam upayanya sebagai menyelamatkan sejarah suatu masyarakat dalam lingkup kewilayahan tertentu dan dalam tingkatan lebih luas menyelematkan sejarah perjalanan bangsa. Kegiatan ini sendiri dilakukan guna menjadikan generasi para sejarawan pada masa yang akan datang dapat mengerti akan pentingnya sebuah sumber dan mau untuk melestarikan serta memanfaatkan sumber tersebut dalam berbagai kepentingan yang melingkupinya, baik yang sifatnya public maupun akademis.

Dalam hal ini kami sebagai peneliti mengajukan saran bahwasanya kegiatan seperti ini perlu untuk dilakukan secara rutin guna mengenalkan arsip dan pelbagai sumber teks kepada para mahasiswa-siswi yang ada di jurusan sejarah agar kemudian mereka menjadi paham dan dekat dengan hal tersebut. Kegiatan ini sendiri dapat dijadikan sebagai sebuah arena pembelajaran di luar kelas perkuliahan sekaligus, ditambah dengan pemahaman melalui kata-kata yang lugas dari para arsiparis membuat kemudian mereka menjadi tergugah dalam melakukan penelahaan menggunakan arsiparsip yang ada ditempat tersebut. Di sisi lain, pihak dinas Perpustakaan dan Kearsipan Kabupaten Cirebon pun sangat mendukung acara yang sedang kami lakukan, dalam hal ini realisasi yang dilakukan kemudian adalah dengan melakukan kegiatan ini sebagai agenda rutin yang akan diadakan tahunan sebagai bentuk kerjasama yang baik diantara kedua belah pihak.

\section{Daftar Pustaka}

Irkham, Gol. A. Gong. \& A. M. (2012). Gempa Literasi. Kepustakaan Populer Gramedia.

Kartodirdjo, S. (2016). Pendekatan IImu Sosial dalam Metodologi Sejarah. Penerbit Ombak.

Kuntowijoyo. (2005). Pengantar Ilmu Sejarah. Penerbit Bentang.

Notosusanto, N. (1965). Hakekat Sejarah dan Azas-Azas Metode Sejarah. Mega Bookstore - Pusjarah ABRI.

Padiatra, A. M. (2020). IImu Sejarah: Metode dan Praktik. Jendela Sastra Indonesia Press. Poerwantana, Hugiono. \& P. (1992). Pengantar Ilmu Sejarah. Penerbit Rineka Cipta.

Wursanto. (1991). Kearsipan 1. Kanisius. 